\title{
Effect of Simulated Microgravity on Sexual Development of Female Japanese Quail
}

\author{
P. ŠKROBÁNEK, M. BARANOVSKÁ, B. ŠÁRNIKOVÁ, M. JURÁNI \\ Institute of Animal Biochemistry and Genetics, Slovak Academy of Sciences, Ivanka pri Dunaji, \\ Slovak Republic \\ Received April 23, 2007 \\ Accepted December 19, 2007
}

\begin{abstract}
Škrobánek P., M. Baranovská, B. Šárniková, M. Juráni: Effect of Simulated Microgravity on Sexual Development of Female Japanese Quail. Acta Vet Brno 2008, 77: 3-10.

Hypodynamia is a method to simulate weightlessness (microgravity) in the laboratory conditions. The objective of this study was to investigate the influence of chronic hypodynamia on the growth and development of the ovary and oviduct, plasma estradiol and progesterone concentration, and the onset of egg-laying in Japanese quail.

The ovary weight gradually increased with age in both groups. However, the experimental birds subjected to hypodynamia showed a significant reduction in ovary weight relative to agematched control between 21 and 42 days of age $(P<0.05)$. The number of yellow follicles with a diameter of less than $10 \mathrm{~mm}$, between 10 and $15 \mathrm{~mm}$ and more than $15 \mathrm{~mm}$ was similar in both groups from 49 days to the end of experiment. The control birds had significantly longer oviduct than those of the test group from 28 to 63 days $(P<0.05)$ with the exception of day 49 . The quail reared under hypodynamia laid their first egg about three days later than control. Plasma progesterone concentration in experimental quail was significantly reduced between 28 and 49 days $(P<0.05)$. Plasma estradiol concentration increased progressively with age in both groups. The differences between the groups were not significant at any age.

These findings suggest that although hypodynamia negatively affects some of the examined variables, the female Japanese quail is able to grow and develop normally under conditions of simulated weightlessness.
\end{abstract}

Hypodynamia, ovary, oviduct, progesterone, estradiol

Since the Earth's gravitational field has remained constant for billions of years, it is assumed that gravity plays a substantial role in the ontogeny of organisms. By means of experiments in weightless environment (microgravity), we should be able to answer questions on the importance of gravity for the development of organisms. Numerous authors have successfully studied different phases of embryogenesis in insects, fishes, amphibians, birds and mammals in microgravity during space flights. It was found, for example, that Japanese quail embryogenesis does not appear to be seriously affected by the conditions of weightlessness (Guryeva et al. 1993; Dadasheva et al. 2001). In experiments aboard the MIR space station, Japanese quail embryos successfully completed embryogenesis and hatched chicks had all the external characteristics of healthy development (Bod'a et al. 1992; Sabo et al. 2001). How microgravity may influence further development of quail chicks is unknown. However, partial answer may be obtained by ground-based animal models simulating microgravity (hypodynamia). The first experiments with hypodynamia in birds were carried out in the adult Japanese quail (Juráni et al. 1983). Twenty years later, the first experiment examining the adaptability of newly hatched Japanese quail chicks to hypodynamia was accomplished (Škrobánek and Hrančová 2003). In further experiment, the post-hatch development of Japanese quail subjected to hypodynamia from 3 to 56 days of age was studied (Škrobánek et al. 2004, 2005).

The objective of this study was to examine the effects of hypodynamia on development of the ovary and oviduct, the plasma concentrations of estradiol and progesterone, and the onset of egg-laying in Japanese quail.

Address for correspondence:

Ing. Peter Škrobánek, CSc.

Institute of Animal Biochemistry and Genetics

Slovak Academy of Sciences

Moyzesova 61

90028 Ivanka pri Dunaji, Slovak Republic

Phone: + 4210245943881

Fax: + 4210245943932

E-mail: ubgzskro@savba.sk

http://www.vfu.cz/acta-vet/actavet.htm 


\section{Materials and Methods}

Seventy 3-day-old female Japanese quail (Laying Line 01 Ivanka pri Dunaji) with mean body weight 10.56 $\pm 0.42 \mathrm{~g}$ were exposed to hypodynamia. Hypodynamia, model simulating weightlessness characterized by the absence of weight-bearing and by a decrease in motor activity (Morey et al. 1979) was modified in our laboratory for the use in birds (Škrobánek et al. 2004). Hypodynamia was induced in birds by placing them in special individual slings suspended by a flexible wire apparatus in such a way that their legs cannot touch the floor. The size of the slings was enlarged at 7, 14,21, 28 and 35 days of age (from $4 \times 3 \mathrm{~cm}$ to $5 \times 4 \mathrm{~cm}$ to $6 \times 5 \mathrm{~cm}$ to $7 \times 6 \mathrm{~cm}$ and $8 \times 7 \mathrm{~cm}$ ) to accommodate the growth of the quail. At the same time, seventy quail chicks (control group) were placed in a rearing box $(120 \times 60 \times 30 \mathrm{~cm})$. The birds of both hypodynamia and control group were kept until 63 days of age in a windowless poultry room with controlled ventilation and heating (infrared lamps). The temperature in the rearing room was maintained at approximately $35-36{ }^{\circ} \mathrm{C}$ for the first few days after hatching, then decreased gradually during four weeks to about $20^{\circ} \mathrm{C}$ and remained at this level until the end of experiment. A commercial starter mash HYD-13 and water were available ad libitum. The granular diet containing $260 \mathrm{~g} / \mathrm{kg}$ protein and $11.5 \mathrm{MJ}$ metabolisable energy $/ \mathrm{kg}$ was fed from the hatch to the termination of experiment. Birds were provided with continuous lighting throughout the whole experiment. The care and use of animals were in accordance with laws and regulations of the Slovak Republic and approved by the Ethical Committee of the Institute of Animal Biochemistry and Genetics, Slovak Academy of Sciences, Ivanka pri Dunaji.

At 21, 28, 35, 42, 49, 56 and 63 days of age, ten birds were randomly selected from hypodynamia and control group for the assessment of the degree of their reproductive development. Birds were individually weighed and euthanized by decapitation. The blood samples were collected from a jugular vein using heparinised glass tubes and centrifuged at $1500 \mathrm{~g}$ for $30 \mathrm{~min}$ at $4{ }^{\circ} \mathrm{C}$ to separate the plasma. The plasma was stored at $-20^{\circ} \mathrm{C}$ until estradiol and progesterone radioimmunoassay (Immunotech, Slovakia) was performed. Decapitation and blood collection was always carried out between 8:00 and 9:30 $\mathrm{h}$.

Immediately after blood collection, the abdominal cavity was opened; the ovary was removed and weighed. The number of yellow ovarian follicles (with diameter $<10 \mathrm{~mm}$, between 10 and $15 \mathrm{~mm}$, and $>15 \mathrm{~mm}$ ) was recorded. The left oviduct was dissected and its length measured.

The age of sexual maturity (the first egg) of the remaining hens was also recorded. Data from both groups were analyzed by two-way analysis of variance (ANOVA) with the age and treatment as factors. In each analysis, significant differences among means were detected using Tukey multiple comparison test. In all cases the level of significance was set at $P<0.05$. All values are presented as mean \pm SEM.

\section{Results}

The mean body weight of hens in both groups increased with age (Fig. 1). However, the control birds were heavier than those from the hypodynamia group. The body weight of hypodynamia quail between 21 and 63 days was by 18 to $26 \%$ less than that of the agematched control $(P<0.05)$.

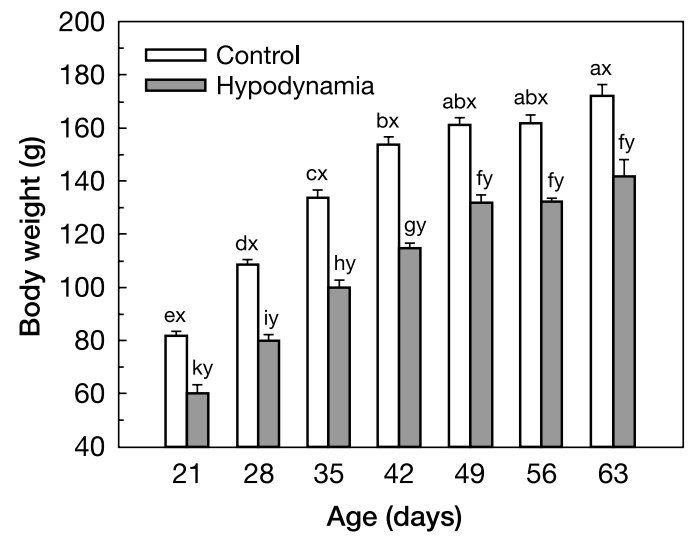

Fig. 1. The mean body weight of female Japanese quail developing in simulated microgravity.Values are means $\pm \mathrm{SEM}, \mathrm{n}=10$.

$(\mathrm{a}, \mathrm{b}, \mathrm{c}, \mathrm{d}, \mathrm{e})$ Means of control with different superscripts are significantly different $(P<0.05)$

$(\mathrm{f}, \mathrm{g}, \mathrm{h}, \mathrm{i}, \mathrm{k})$ Means of hypodynamia with different superscripts are significantly different $(P<0.05)$

${ }^{(x, y)}$ Means of control and hypodynamia with different superscripts are significantly different $(P<0.05)$ 
The ovaries of control quail were heavier than those of the hypodynamia group from day 21 till the end of experiment. On days 49, 56 and 63, these differences were not significant (Fig. 2).

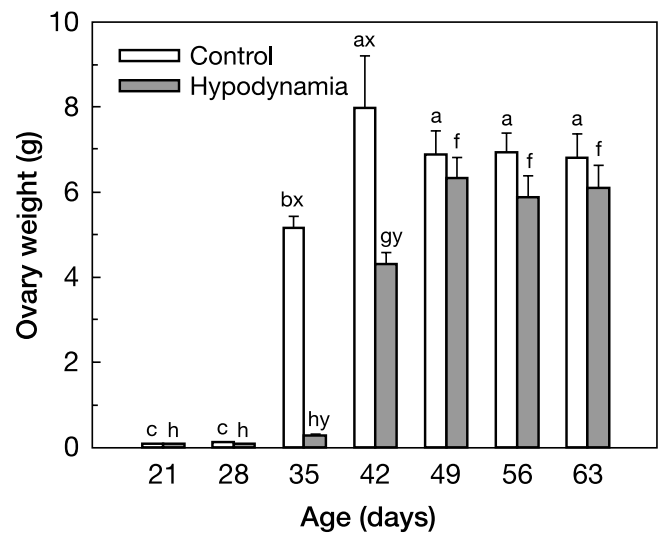

Fig. 2. The mean ovary weight of Japanese quail developing in simulated microgravity. Values are means \pm SEM, $\mathrm{n}=10$.

$(\mathrm{a}, \mathrm{b}, \mathrm{c})$ Means of control with different superscripts are significantly different $(P<0.05)$

$(\mathrm{f}, \mathrm{g}, \mathrm{h})$ Means of hypodynamia with different superscripts are significantly different $(P<0.05)$

${ }^{(x, y)}$ Means of control and hypodynamia with different superscripts are significantly different $(P<0.05)$
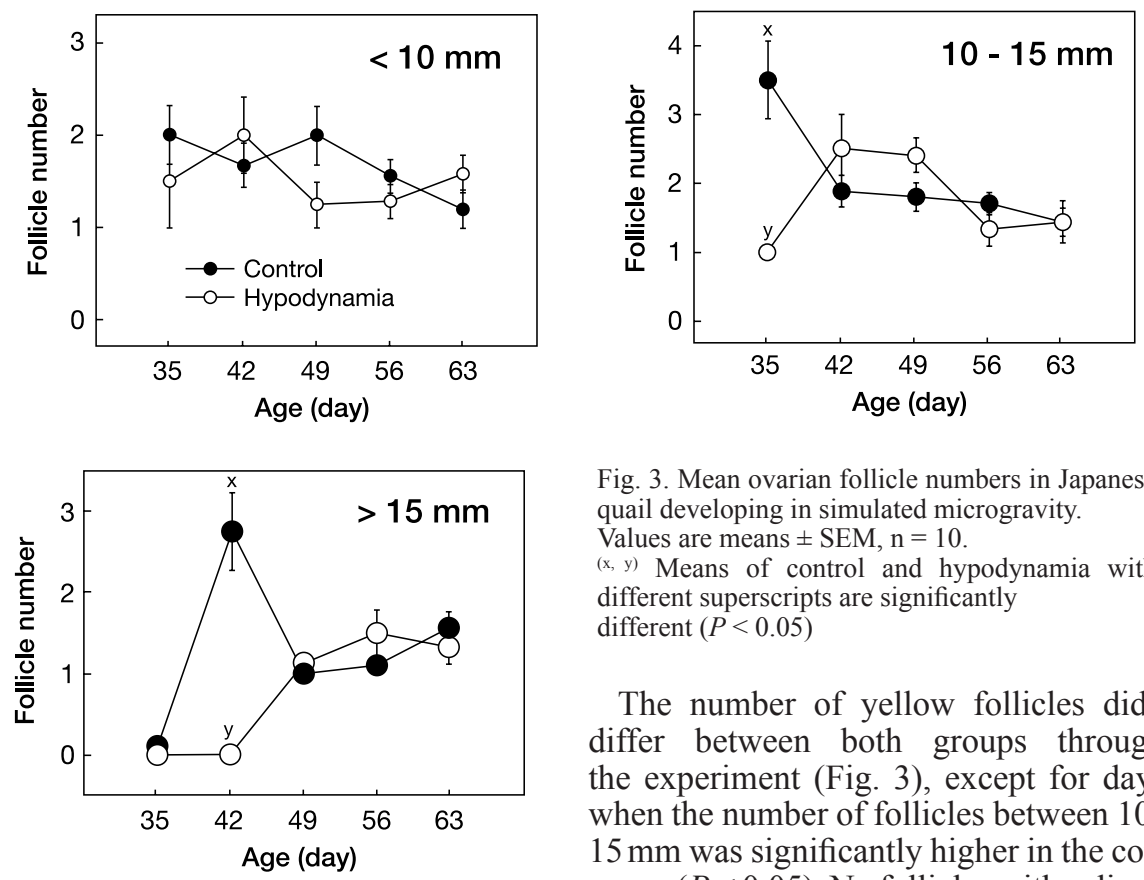

Fig. 3. Mean ovarian follicle numbers in Japanese quail developing in simulated microgravity. Values are means $\pm \mathrm{SEM}, \mathrm{n}=10$.

$(x, y)$ Means of control and hypodynamia with different superscripts are significantly different $(P<0.05)$

The number of yellow follicles did not differ between both groups throughout the experiment (Fig. 3), except for day 35, when the number of follicles between 10 and $15 \mathrm{~mm}$ was significantly higher in the control group $(P<0.05)$. No follicles with a diameter exceeding $15 \mathrm{~mm}$ were recorded in the control and hypodynamia birds at 35 days. On day 42 , the control group had significantly $(P<0.05)$ more follicles with a diameter larger than $15 \mathrm{~mm}$. No significant differences were observed on days 49, 56 and 63, when the number of follicles in both groups was approximately the same. 
The oviducts of the control in comparison with hypodynamia quail $(P<0.05)$ were longer on day 28, 42, 56 and 63. On day 21 and 49, the observed differences in the oviduct length between hypodynamia and control group were not significant (Fig. 4).

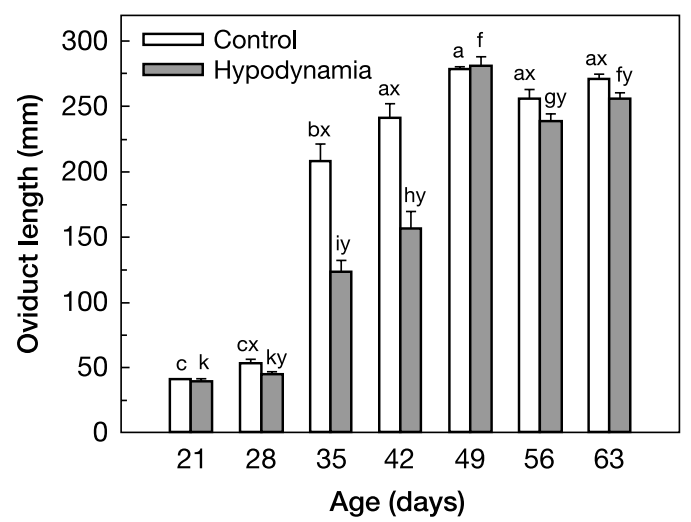

Fig. 4. The mean oviduct length of Japanese quail developing in simulated microgravity. Values are means \pm $\mathrm{SEM}, \mathrm{n}=10$.

$(\mathrm{a}, \mathrm{b}, \mathrm{c})$ Means of control with different superscripts are significantly different $(P<0.05)$

$(\mathrm{f}, \mathrm{g}, \mathrm{h}, \mathrm{i})$ Means of hypodynamia with different superscripts are significantly different $(P<0.05)$

${ }^{(\mathrm{x}, \mathrm{y})}$ Means of control and hypodynamia with different superscripts are significantly different $(P<0.05)$

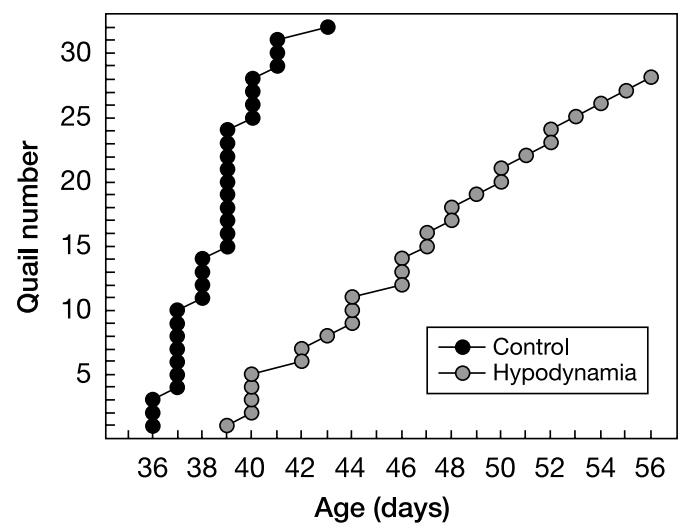

Fig. 5. The onset of oviposition (the first egg) in Japanese quail developing in simulated microgravity.

Control quail laid the first egg earlier than those from the hypodynamia group (Fig. 5). For example, the control quail began to lay eggs on day 36 (three birds), whereas the hypodynamia quail (one bird) laid their first egg on day 39 of age. Most of the control birds laid their first egg between days 37 and 39. The birds reared under hypodynamia laid their first egg between days 40 and 56. Four hypodynamia quail laid no egg. Their body weight was still below $120 \mathrm{~g}$ on day 63 . The sexual maturity of the control and hypodynamia groups was reached on days 42 and 54, respectively $(P<0.05)$. The mean weight of the first eggs did not differ between both groups (data not shown).

The plasma progesterone concentration was significantly reduced $(P<0.05)$ in quail reared under hypodynamia on days $28,35,42$ and 49 in comparison with the control (Fig. 6). No significant differences, however, were observed on days 56 and 63. The results 


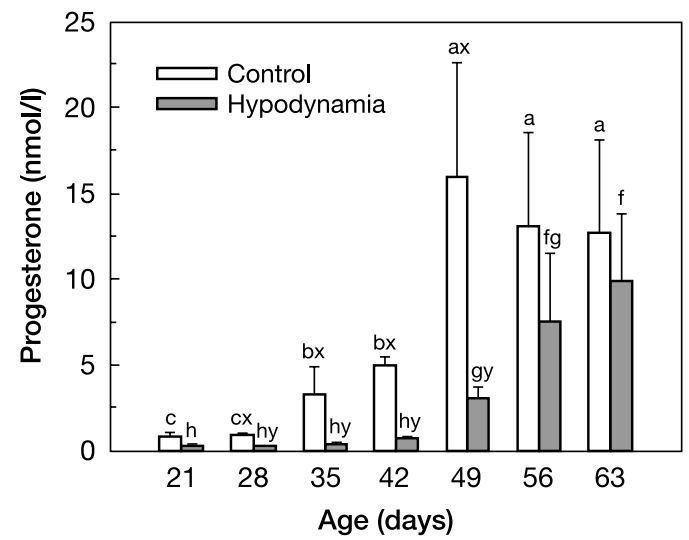

Fig. 6. Concentration of plasma progesterone in female Japanese quail developing in simulated microgravity. Values are means $\pm \mathrm{SEM}, \mathrm{n}=10$.

$(\mathrm{a}, \mathrm{b}, \mathrm{c})$ Means of control with different superscripts are significantly different $(P<0.05)$

$(\mathrm{f}, \mathrm{g}, \mathrm{h})$ Means of hypodynamia with different superscripts are significantly different $(P<0.05)$

${ }^{(\mathrm{x}, \mathrm{y})}$ Means of control and hypodynamia with different superscripts are significantly different $(P<0.05)$

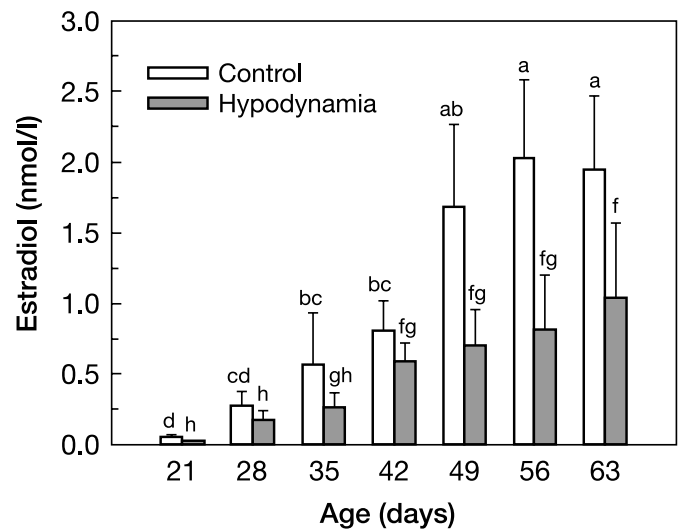

Fig. 7. Concentration of plasma estradiol in female Japanese quail developing in simulated microgravity. Values are means \pm SEM, $\mathrm{n}=10$.

(a, b, c) Means of control with different superscripts are significantly different $(P<0.05)$

(f,g, h) Means of hypodynamia with different superscripts are significantly different $(P<0.05)$

confirm that plasma progesterone generally increased with age, although in birds subjected to hypodynamia this rise was delayed.

The plasma estradiol concentration in female Japanese quail increased progressively with age in both groups (Fig. 7). Although the mean estradiol levels in birds developing in hypodynamia were lower throughout the entire experiment, this difference did not reach the level of statistical significance.

\section{Discussion}

There are many studies that characterise development of reproduction organs in Japanese quail under standard earth conditions. It has been reported that the growth rate of the ovary and oviduct in Japanese quail was faster under a daily light period of 14 or more hours (Wilson et al. 1962), and that oviduct started to grow very rapidly between 21 and 28 days 
of age and reached adult weight by 45 days (Pageaux et al. 1984). The plasma progesterone concentration significantly increased from 6 to 10 weeks of age, and plasma estradiol levels also tended to increase between 6 and 13 weeks of age, but the alteration was not significant (Tsutsui et al. 1998). The onset of egg-laying in quail, which is synonymous to the onset of sexual maturity, depends on several biological factors, such as body weight (Zelenka et al. 1984) and age (Yannakopoulos et al. 1995). The age of sexual maturity and the body weight at sexual maturity was positively correlated in the random-bred quail line but did not show the same relationship in the growth-selected line (Reddish et al. 2003). It was also demonstrated that although full-fed broiler breeder pullets may obtain this body weight by 14 or 15 weeks, they do not commence to lay until 24 or 25 weeks, suggesting that an age threshold must also be achieved (Leeson and Summers 1982).

The aim of the present study was to investigate the effect of hypodynamia on the development of reproductive organs in female Japanese quail. Our results showed that development of the investigated variables was mostly similar in both groups, although both oviduct and ovary in quail exposed to hypodynamia developed more slowly, plasma concentrations of estradiol and progesterone were lower and their first egg was laid later than in the age-matched control. For a comparison of the present experiment data with the results of the above mentioned studies, it is necessary to state that partial differences in the tested reproduction variables of the control birds could be due to the use of different strains and breeding technology.

The changes observed in our study were not entirely unexpected. It is widely accepted that hypodynamia acts as a stress factor (Juráni et al. 1991), although the mechanisms underlying the inhibitory effects of hypodynamia on the development of Japanese quail are not fully understood. For example, approximately $75 \%$ of quail chicks exposed to hypodynamia from either the first, second or third day of age till 21 days of age were not able to adapt to altered living conditions (Škrobánek and Hrančová 2003). Hypodynamia had a profound negative influence on food consumption and conversion in Japanese quail chicks. It also induced a significant decrease in the lengths of quail femur, tibiotarsus and tarsometatarsus as early as at 7 days of age (Škrobánek et al. 2004). Hypodynamia also evoked significant changes in growth and mineral deposition of leg long bones in quail chicks (Škrobánek et al. 2005). Moreover, it had a significant impact on the weight, dry matter, content of proteins, lipids and glycogen in muscles and liver of female Japanese quail between 3 and 56 days of age (Šk krobánek et al. 2007). Simulated microgravity also induced a hypertrophy of quail adrenal glands (Cigánková et al. 2005).

In adult Japanese quail, hypodynamia reduced periosteal bone formation and tubular bone growth (Guryeva et al. 1998) and induced morphological differences in striated muscles (Kočišová et al. 1998). The body weight of birds subjected to 84 days lasting hypodynamia decreased by about $14 \%$ (Sabo et al. 1998). In another experiment, the plasma estradiol content in quail under hypodynamia was significantly decreased already on day 7 (Juráni et al. 1984). Likewise, hypodynamia treatment evoked different changes in the mineral metabolism in male and female Japanese quail (Antalíková et al. 2001; Sviatko et al. 1998).

Similar responses were observed in adult quail after 7-day exposure to microgravity aboard the orbital space station MIR. During that time, the body weight of three quail females decreased from 151 to $96 \mathrm{~g}$ (Sabo et al. 1992). Also, the mean body weight of 4-5-day-old quail chicks hatched and kept in weightlessness was reduced by $26-30 \%$ than that of control birds reared on Earth (Dadasheva et al. 2001).

In adult rats, significant effect of gravitational unloading on motor performance was observed (Kawano et al. 2000). Moreover, the body and hindlimb muscle weight in rats were significantly lower after 9 weeks of hindlimb-unloading as compared to the agematched weight-bearing controls (Ohira et al. 2002). 
This report is the first study examining the effect of hypodynamia (simulated microgravity) on sexual development of female Japanese quail. The obtained results indicate that hypodynamia has a significant impact on the oviduct length and the plasma progesterone concentration. The differences between other reproductive indicators were not significant, except for the age when the first egg was laid.

Together with our previous experiments, this data may contribute to the understanding of quail development under conditions of real microgravity.

\section{Vplyv simulovanej mikrogravitácie na sexuálny vývin sliepočiek prepelice japonskej}

V laboratórnych podmienkach ako metóda simulácie beztiažového stavu je využívaná hypodynamia. Ciel'om našej práce bolo skúmat' vplyv chronickej hypodynamie na rast a vývin vaječníka a vajcovodu, koncentráciu plazmatického estradiolu a progesterónu, ako aj na začiatok znášky u prepelice japonskej.

Hmotnost' vaječníkov sa zvyšovala postupne s vekom u obidvoch skupín prepelíc. Vtáky pokusnej skupiny vystavenej hypodynamii mali však významne nižšiu hmotnost' vaječníkov medzi 21. a 42. dňom veku v porovnaní s kontrolou $(P<0,05)$. Počet žltých folikulov s priemerom menším ako 10 , medzi 10 a 15 a väčším ako $15 \mathrm{~mm}$ bol podobný u obidvoch skupín od 49. dňa až do konca experimentu. Kontrola mala signifikantne dlhší vajcovod ako pokusné vtáky od 28 do 63 dní veku $(P<0,05)$, s výnimkou v 49 dňoch. Prepelice odchovávané $\mathrm{v}$ hypodynamii zniesli svoje prvé vajce o tri dni neskôr ako kontrola. Koncentrácia plazmatického progesterónu u pokusnej prepelice bola signifikantne znížená od 28. do 49. dňa $(P<0,05)$. Koncentrácia plazmatického estradiolu sa progresívne zvyšovala u obidvoch skupín, pričom rozdiely medzi nimi neboli významné.

Dosiahnuté výsledky opät' naznačili, že hoci hypodynamia pôsobila na niektoré z posudzovaných ukazovatel'ov negatívne, samice prepelice japonskej boli schopné rást' a vyvíjat' sa v podmienkach simulovaného beztiažového stavu.

\section{Acknowledgement}

This work was supported by the Grant Agency for Science of the Slovak Republic, VEGA grant No. 2/6024/26.

\section{References}

ANTALÍKOVÁ J, BARANOVSKÁ M, MRAVCOVÁ I, SABO V, ŠKROBÁNEK P 2001: Different influence of hypodynamy on calcium and phosphorus levels in bones of male and female Japanese quails. Physiol Res 50: $197-204$

BOĎA K, SABO V, JURÁNI M, GURYEVA TS, KOČIŠOVÁ J, KOŠŤÁL L', LAUKOVÁ A, DADASHEVA OA 1992: Embryonic development and behaviour of Japanese quail exposed to microgravity. Acta Vet Brno 61: $99-107$

CIGÁNKOVÁ V, ZIBRÍN M, BOĎA K, HOLOVSKÁ K 2005: Effect of long-term experimental hypodynamy on the adrenal glands of Japanese quails: An ultrastructural study. Bull Vet Inst Pulawy 49: 449-453

DADASHEVA OA, GURYEVA TS, SABO V, BOĎA K, KOČIŚOVÁ J 2001: Research into morphology of Japanese quails chicks hatched under conditions of microgravity. Folia Vet 45: S12-S16

GURYEVA TS, DADASHEVA OA, MELESHKO GI, SHEPELEV YE YA, BOĎ K, SABO V 1993: The quail embryonic development under the conditions of weightlessness. Acta Vet Brno 62: S25-S30

GURYEVA TS, MEDNIKOVA EI, DADASHEVA OA, POVALKO NB 1998: The musculoskeletal apparatus of Japanese quail during hypodynamy. Folia Vet 42: S37-S39

JURÁNI M, BOĎA K, VÝBOH P, ZEMAN M, LAMOŠOVÁ D, SOMOGYIOVÁ E, KOŠŤÁL L', BAUMGARTNER J 1991: An endocrine response to short-term hypodynamy in Japanese quail selected for resistance to hypodynamy. Physiologist 34: S129-S131

JURÁNI M, VÝBOH P, LAMOŠOVẢ D, BAROŠKOVÁ Ž, SOMOGYIOVÁ E, BOĎA K, GAŽO M 1983: The effect of a 90-day hypodynamy on the neurohumoral system, egg laying and metabolism of proteins in Japanese quail. Physiologist 26: S145-S148

JURÁNI M, VÝBOH P, LAMOŠOVÁ D, BOĎA K, NVOTA J 1984: Neurophysiological response of Japanese quail to a short- and long-term restraint. In: BODA K (Ed.): Cosmic Biology - Gravitational Physiology. SAV, Ustav fyziológie hospodárskych zvierat, Košice, pp. 29-43 
KAWANO F, NOMURA T, KANG MS, LEE JH, HAN EY, CHIU YC, SATO Y, ISHIHARA A, OHIRA Y 2000: Effects of 9 weeks of hindlimb unloading on motor performances in adult rats. J Grav Physiol 7: 115-116

KOČIŠOVÁ J, SABO V, TOMAJKOVÁ E, BOĎA K 1998: Morphological changes in $m$. gastrocnemius during hypodynamy. Folia Vet 42: S41-S44

LEESON S, SUMMERS JD 1982: Consequence of increased feed allowance for growing broiler breeder pullets as a means of stimulating early maturity. Poult Sci 62: 6-11

MOREY ER, SABELMAN EE, TURNER RT, BAYLINK DJ 1979: A new rat model simulating some aspects of space flight. Physiologist 22: S23-S24

OHIRA Y, NOMURA T, KAWANO F, SATO Y, ISHIHARA A, NONAKA I 2002: Effects of nine weeks of unloading on neuromuscular activities in adult rats. J Grav Physiol 9: 49-59

PAGEAUX JF, LAUGIER C, PAL D, PACHECO H 1984: Development of the oviduct in quail during sexual maturation in relation to plasma concentration of oestradiol and progesterone. J Endocrinol 100: 167-173

REDDISH JM, NESTOR KE, LILBURN MS 2003: Effect of selection for growth on onset of sexual maturity in randombred and growth-selected lines of Japanese quail. Poult Sci 82: 187-191

SABO V, BOĎA K, GURYEVA TS, DADASHEVA OA 1992: Changes in the body and organ mass of Japanese quail after a 7-day exposure to microgravity. Acta Vet Brno 61: 109-113

SABO V, BOĎA K, GURYEVA TS, DADASHEVA OA, BELLA I 2001: The study of postembryonic development of Japanese quail chicks under microgravity and load on the orbital station MIR. Folia Vet 45: S9-S11

SABO V, CHRAPPA V, BOĎA K 1998: Effect of long-term (84-days) hypodynamy on the efficiency of Japanese quails. Folia Vet 42: S59-S63

SVIATKO P, BODA K, SABO V 1998: The effect of hypodynamy on the content of mineral substances in the femur and tibiotarsus of Japanese quails. Folia Vet 42: S45-S49

ŠKROBÁNEK P, BARANOVSKÁ M, JURÁNI M, ŠÁRNIKOVÁ B 2005: Influence of simulated microgravity on leg bone development in Japanese quail chicks. Acta Vet Brno 74: 475-481

ŠKROBÁNEK P, BARANOVSKÁ M, ŚÁRNIKOVÁ B, JURÁNI M 2007: Effect of simulated microgravity on metabolite concentrations in the muscles and liver of developing Japanese quail chicks. Acta Vet Brno 76: 9-16

ŠKROBÁNEK P, HRANČOVÁ M 2003: Adaptability of Japanese quail chicks to conditions of simulated weightlessness. Acta Vet Brno 72: 347-351

ŠKROBÁNEK P, HRBATÁ M, BARANOVSKÁ M, JURANI M 2004: Growth of Japanese quail chicks in simulated weightlessness. Acta Vet Brno 73: 157-164

WILSON WO, ABPLANALP H, ARRINGTON L 1962: Sexual development of Coturnix as affected by changes in photoperiods. Poult Sci 41:17-22

TSUTSUI K, LI D, UKENA K, KIKUCHI M, ISHII S 1998: Developmental changes in galanin receptors in the quail oviduct and the effect of ovarian sex steroids on galanin receptor induction. Endocrinology 139: 42304236

YANNAKOPOULOS AL, CHRISTAKI E, FLOROU-PANERI P 1995: Effect of age and carcass composition on the onset of sexual maturity in quail under normal feeding regimens. Br Poult Sci 36: 771-777

ZELENKA DJ, CHERRY JA, NIR I, SIEGEL PB 1984: Body weight and composition of Japanese quail (Coturnix coturnix japonica) at sexual maturity. Growth 48: 16-28 